Relations industrielles

Industrial Relations

\title{
Working Life: Renewing Labour Process Analysis, Edited by Paul Thompson and Chris Smith, Houndmills, Basingstoke, UK: Palgrave Macmillan, 2010, 350 pp., ISBN 978-0-230-22223-6
}

\section{Bob Russell}

Volume 66, numéro 1, hiver 2011

URI : https://id.erudit.org/iderudit/1005111ar

DOI : https://doi.org/10.7202/1005111ar

Aller au sommaire du numéro

Éditeur(s)

Département des relations industrielles de l’Université Laval

ISSN

0034-379X (imprimé)

1703-8138 (numérique)

Découvrir la revue

Citer ce compte rendu

Russell, B. (2011). Compte rendu de [Working Life: Renewing Labour Process Analysis, Edited by Paul Thompson and Chris Smith, Houndmills, Basingstoke, UK: Palgrave Macmillan, 2010, 350 pp., ISBN 978-0-230-22223-6]. Relations industrielles / Industrial Relations, 66(1), 151-153.

https://doi.org/10.7202/1005111ar

Tous droits réservés @ C Département des relations industrielles de l’Université Laval, 2011
Ce document est protégé par la loi sur le droit d'auteur. L'utilisation des services d'Érudit (y compris la reproduction) est assujettie à sa politique d'utilisation que vous pouvez consulter en ligne.

https://apropos.erudit.org/fr/usagers/politique-dutilisation/ 
Kelly regards the commitment to ethical socialism as an enduring element in Flanders' views despite the radical alteration of other elements. But the meaning of these ethics was substantially reinterpreted. The idea of 'fellowship' encouraged a vision of the enterprise as a community in which all could and should participate for their mutual benefit. Anti-materialism informed the view that workers' main needs were for voice, dignity and status rather than higher wages, and trade unions should reflect this. The trust in the power of rational discussion persisted. All these assumptions underlay his commitment to incomes policy, productivity bargaining and industrial relations reform. Kelly itemises some of the contradictions in this position: in a society shaped by fundamental class differences of wealth and power, the 'reform' of industrial relations seemed primarily a recipe for re-stabilising capitalism. Workers and their unions refused to buy the package, and by the end of the 1970s - after Flanders' death - the whole reform project had failed. Kelly ends with an epilogue tracing the familiar story of the past three decades: the shift to a coercive anti-union 'solution' to British industrial relations under Thatcher, a policy position not fundamentally altered under subsequent governments; and the further rightwards shift of social democracy towards 'New Labour', a trajectory which, Kelly concludes, involved 'a radical assault on the ethical and democratic socialist project associated with Allan Flanders'.

The book is the product of an intensive process of research, involving a comprehensive reading of Flanders' published and unpublished writings, extensive archival work, and interviews and correspondence with many of his key associates. It has been a long project, with much of the research undertaken more than a decade ago. Kelly certainly disagrees with many of Flanders' ideas and policy interventions, but the account strikes me as fair and not unsympathetic. I have some disagreements.
The failure of the reform project in British industrial relations surely owed something to the specific circumstances of the 1970s: the collapse of the post-war international financial architecture, the oil shock (an outcome was an inflation rate of $24 \%$ in the UK in 1975), the insistence of the Callaghan government at the end of the decade in imposing an incomes policy so restrictive that breakdown was inevitable. None of this could have been predicted while Flanders was still alive. I am also conscious, having for a few years been a student and then a colleague of Flanders and having disagreed profoundly with his politics, that the scenarios developed by those of us on the revolutionary left were as thoroughly discredited as those of the reformists. I also think Kelly is too dismissive of some of the ethics that Flanders espoused. Can we write off the potential of reasoned argument, or is the question rather to diagnose its limits? And is the proposition that trade unions should do more than fight for higher wages necessarily wrong? Marxist theories of alienation - and indeed also of workers' control - have informed strategies which are not wholly at odds with those which Flanders inherited from the ISK.

\section{Richard Hyman}

London School of Economics

\section{Working Life: Renewing Labour Process Analysis}

Edited by Paul Thompson and Chris Smith, Houndmills, Basingstoke, UK: Palgrave Macmillan, 2010, 350 pp., ISBN 978-0-23022223-6

Each year a volume of essays is published in connection with the convening of the International Labour Process Conference. Usually, these collections are devoted to a specific theme such as skill trends in contemporary economies, work-life balance, creative labour or knowledge management. This volume stands out as one of the periodic paradigm 'stock taking' exercises, only the second such initiative since 1990 . Thus 
there is a considerable range to this collection, which covers both familiar topics such as developments in managerial control, as well as new and/or re-discovered initiatives that involve dialogue with other schools of social theory.

The book is conveniently divided into three sections: 'core theory'; old themes revisited; and the analysis of new realities in the world of work. A number of authors in the first section are mainly concerned with formalising what they take to be the core propositions of labour process theory (LPT). Chief amongst these propositions is the inherent indeterminacy of labour in the capitalist labour process. This fundamental condition is taken to lead to a number of other core propositions, including the necessity of management, the relative autonomy of the work site, the existence of structured antagonisms between management and labour and a now commonly accepted anti-historicism in LPT. A number of the chapters in this section, including those by Edwards and Jaros seek to formally delimit labour process theory in terms of what it is capable of doing. For example LPT should eschew venturing into other areas of social analysis such as gender studies, or race and ethnicity, which require their own core theories (Jaros). Presumably, this is part of the "serious theory-building project that has elucidated 'testable' core propositions that elucidate patterns and propositions discovered through relevant research programmes" that Thompson and Smith call for in their introductory chapter. I must admit to some reservations in regard to this program. It strikes me that many of the most significant conceptual developments in LPT (e.g. Burawoy's analysis of consent; Hockschild's conceptualization of emotional labour) have come through inductive theorising from qualitative, ethnographic data. Perhaps there should be less concern with normalising what it is we think we are doing.
Calls to delimit and formalise LPT seem to sit at odds with the expansionary theoretical focus of many of the papers in this volume. Chapters by Thompson and Vincent, Taylor, and Thompson and Smith call for better integration with political economic theory. In Chapter 3, Thompson and Vincent consider the utility of various paradigms, including regulation theory, varieties of capitalism typologies and global value chain analysis. Meanwhile Taylor puts the latter to good use in Chapter 12, which considers the globalization of service labour and the attendant problems of managerial control in off-shore, outsourced custom service work that is exported to India. Other chapters also look theoretically afield to radical geography and spatial analysis (Rainnie et al.), to social constructionist approaches (Hall), to intersectional analyses of oppression (Durbin and Conley), and to the sociology of the body (Wolkowitz and Warhurst). These various approaches are used to redress both old problems in the study of the labour process as well as new empirical developments in the world of work.

Under the recurrent issues rubric, chapters on managerial control, skill trends, technological change and resistance make important contributions. Sturdy et al. put forward the notion of 'neo-normative' control in Chapter 6. This strategy moves beyond normative corporate cultural control by using aspects of popular culture such as individualism and fashion to control employees who are now encouraged to 'be themselves'. Although the authors make the important point that various forms of control are most often combined in any given workplace, one wonders whether the promotion of 'identity freedom' is largely restricted to young workforces in customer service work.

In their treatment of another common LPT theme, Grugulis and Lloyd contribute a very useful chapter on the ever more contentious issue of skill. While noting 
that discretion in work actually seems to be declining, the authors also consider the important issue of changes to the notion of skill and the particularly troublesome issue of so-called 'soft' skills such as abilities to engage in team work and to communicate and present well. On this point, the authors issue a timely cautionary note, warning against a dilution of the concept of skill, while, (more contentiously), suggesting a displacement of studies focusing on skill with an analytical refocusing on job quality. Hall's chapter on technology contributes further to some of these themes. Arguing for a social constructivist approach that recognizes the realities of power in the labour process, Hall draws our attention to the contested terrain which technological adoption has become. His case study of Enterprise Resource Planning systems shows how such software both centralizes control, decentralizes responsibility and generates new forms of resistance.

Another recurrent theme is treated in Chapter 7 by Bélanger and Thuderoz. These authors put forward a useful template for the analysis of worker resistance, jointly locating work groups on a work commitment/opposition continuum and on a managerial control scale that ranges from the subjection of employees to control through responsibilization. Various locations on the grid, such as high levels of work commitment combined with opposition to management are then discussed through reference to empirical case studies. This approach strikes me as being very useful for extending the study of resistance into post-industrial work settings where classic confrontations between labour and capital are less frequent but new forms of resistance are simultaneously being manifested.

Other chapters in the collection open up newer themes. Here special mention should be made of the chapter by Rainnie et al. which argues for spatially informed studies of the labour process. Particularly interesting here is a discussion of spatial strategies in union organizing (workplace organization, global unions, community/ social unionism) as well as the prospect of organizing at spaces of consumption as well as points of production. Relatedly, Smith treats us to a novel extension of the notion of labour power's indeterminacy in Chapter 13. According to Smith, contemporary labour process researchers not only need to consider how labour is extracted from labour power but also take note of the mobility power of labour, which is seen to be increasing with contemporary forms of flexible employment. For more highly skilled labour at least, management must not only be concerned with optimal use of labour power, but also with retention. The article also contains useful critiques of both human capital theory and resource based theories of human resource management.

Another extension of existing analysis is found in Chapter 11 by Wolkowitz and Warhurst, where they consider how worker's bodies are increasingly subjected to commodification in service oriented economies. Increasingly workers are expected to have a certain 'look', voice or aesthetic of self presentation, which may be easier to recruit than to train. Such expectations also have implications for how labour power is reproduced in contemporary consumer oriented societies. Interestingly the implications of this analysis are quite different from those that issue from a theory of neonormative control as is found in Chapter 6 .

As a collection, Working Life is at its strongest when its contributions are confronting the new realities of work and chiefly the changes that have been wrought on work, workers and organizing by the shift to a service economy and by the globalization of economic activity. In so doing the continuing relevance of LPT is placed on open display.

\section{Bob Russell}

Griffith University 